\title{
University Flipped Class Model in China
}

\author{
Shuo Zhao',2, Xin Zhang² \\ ${ }^{1}$ School of Foreign Studies, Xi'an University, Xi'an, China \\ ${ }^{2}$ School of Foreign Studies, Northwestern Polytechnical University, Xi'an, China \\ Email: 1754224618@qq.com
}

How to cite this paper: Zhao, S. and Zhang, X. (2019) University Flipped Class Model in China. Open Journal of Social Sciences, 7, 518-524.

https://doi.org/10.4236/jss.2019.73043

Received: March 12, 2019

Accepted: March 26, 2019

Published: March 29, 2019

\begin{abstract}
Under the wave of information-based education reform in China, the flipped classroom originated from American educational circles, guided by constructivism and relying on modern information technology, as an innovative teaching mode, is attracting the attention and favor of our educational circles with its unique advantages. Guided by the reform of education, this paper conducted a research on the application of flipped classroom teaching mode in university teaching. In the half-year term teaching experiment, the teaching effect of this mode and the acceptability of students were mainly discussed through questionnaires and empirical research on final scores. The result shows that compared with conventional teaching, this model can significantly improve students' learning effect, optimize the learning process, improve students' learning attitude, and is recognized by the majority of students.
\end{abstract}

\section{Keywords}

Flipped Classroom, University, Empirical Research

\section{Introduction}

In recent years, the concept and method of flipped classroom have become popular all over the world, and gradually become the focus of attention in the education circle in the world. The western mainstream media have also given high attention and positive reports to flipped classroom. Since 2011 Chinese researchers have started empirical research on flipped classroom teaching. In recent years, many researchers have conducted various research and practice from various aspects and fields. Undoubtedly flipped classroom has become a hot topic of information education in China. 


\section{Definition and Development of Flipping Classroom Model}

\subsection{Definition of Flipping Classroom Model}

Flipped Classroom, also known as Inverted Classroom, or FCM, refers to a teacher who, on the basis of teaching content, combines the key points, difficulties and some new knowledge of the course to create relevant teaching videos. The students use after-class time to learn a new course by watching their teaching video, which is the process of learning their knowledge. According to the teaching video, students should independently complete the learning tasks so as to absorb and internalize the new knowledge, and then take questions in the learning process to participate in the interaction, cooperation, sharing and discussion between teachers and students in class in order to realize their complete understanding and proficiency of the new knowledge and complete the learning process.

Flipped classroom is simply to reverse the traditional knowledge transmission and internalization [1]. Alternatively the transfer of knowledge is completed independently by students after class while the internalization of knowledge is realized in class.

\subsection{Development of Flipped Classroom Model}

At first, flipped classroom mode was only a small scale teaching exploration carried out by some teachers to solve the teaching difficulties caused by time, place and other factors between teachers and students. For example, in the early 1990s, professor Eric Mazur of Harvard University tried to carry out the practice and research of flipped classroom mode to take care of students who could not keep up with the teaching progress [2]. In 2004, Salman Khan, an American, adopted the method of recording and sharing teaching video to solve his cousin's math problems. In 2007, Jon Bergmann and Aaron Sams, two American high school chemistry teachers, recorded and Shared video teaching practice in order to make up lessons for students who could not attend classes regularly [3].

However, strictly speaking, these researchers' teaching explorations only have some features of flipped classroom. In 2000 J. Wesley Baker of Sedaville University submitted the paper "The Classroom Flip: Using Web Course Management Tools to Become The Guide by the Side" to The 11th international conference on university teaching and the flipped classroom model was endowed with academic concepts [4]. In terms of influence and impetus, 2011 should be the most symbolic year for the development of flipped classroom. Flipped classroom has been spread all over the world, attracting the attention and imitation of teachers all over the world.

\subsection{Practice of MTI Flipped Classroom}

At present, with the expansion of Chinese talent market demand, colleges and universities also expand enrollment. In the process of MTI teaching, the teaching workload of teachers is further increasing and the class is becoming larger num- 
ber. Moreover, the existence of multiple learning methods increases the learning content of students, but the number of class hours of teachers is decreasing, which makes teachers do not know how to teach efficiently. At the same time teachers cannot take care of each student's learning in the teaching process, and the lack of students' self-efficacy triggers classroom silence in university teaching courses prominent at the present stage.

Now domestic and foreign research shows that flipped classroom can give full play to the main role of students in learning, significantly enhance the communication and interaction between teachers and students as well as between students, and promote students' interest in learning and the improvement of learning efficiency. Therefore, we carried out flipped classroom research in university teaching process.

\subsection{Research Method}

In the course of the semester between August and December, 2018, we make experiment of students from a university in Xi'an according to the student's enrollment scores, the students were randomly assigned to experimental class and control class (the number of students is about 36, and each class is about 18). Before the experiment, the comprehensive level of the two classes was tested with the same translation article. Through the test, the results of the experimental class and the control class showed no significant difference, that is, the comprehensive translation ability of the two classes was same.

The control class adopts the traditional translation teaching mode. In the class, teachers decide the teaching objectives and teaching contents. Teachers are the center, students listen and memorize passively. The experimental class adopts the flipped teaching mode, which includes: 1) before class: teachers and students jointly determine the learning tasks; 2) in class: study in groups and complete and solve the problem; 3) after class: students study again and present the learning results in the next class; finally revise the teaching process together. This kind of teaching has transformed the teaching mode from the traditional teacher-centered teaching to the student-centered teaching. Students can learn independently according to their ability to accept, and they do not have to worry about missing knowledge because they are not focused. After repeated thinking, middle school students will have a deeper understanding of knowledge, and use knowledge naturally after class. At this time, the role of teachers really realized the transformation from knowledge impart to learning promoter.

\subsection{Specific Measure}

Before teaching the teacher and the experimental class students made clear the learning form and main tasks of the semester, divided the experimental class students into several groups, elected class representatives and group leaders, determined the group leader responsibility system with class representatives as the main group, and established the corresponding QQ group. In accordance with 
the syllabus and teaching plan, the teacher decides the task book of this semester with the course representatives and team leaders in the first week of teaching. Meanwhile, video of recorded teaching, text materials and learning resources are sent to students to learn the relevant knowledge in advance.

In the learning process, teachers participate in the discussion of student groups and supervise the learning process of students through QQ groups or discussion groups. At the same time, a group leader organizes and supervises the learning process of team members, and communicates with teachers and gives feedback in a timely manner. Students are free to choose when, where and how they want to study. For example, students may learn tourism English-history, culture, scenic spot English translation and other related knowledge. Students can make use of their geographical advantages to collect relevant information at nearby tourist attractions and consult teachers of relevant majors.

In this way, students can learn in real situations, which is convenient for them to assimilate and adapt to the new knowledge they have learned by using the relevant experience in their original cognitive structure, so as to grasp the knowledge more firmly and profoundly.

In class students present their learning experience and problems in groups in the form of short films, PPT or speeches. Teachers and classmates observe and judge students' learning effects and give corresponding suggestions. Teachers focus on solving outstanding problems and communicate with each other individually. Teachers and students put forward improved knowledge and solution [5]. Class representatives and group leaders set up students' English learning files based on the pre-class learning situation, and make mutual evaluation among groups.

Through the display and communication of the previous link, students have a better understanding of their own and classmates' learning situation, and they can learn from each other and make up for shortcomings so as to promote students to form a learning atmosphere of mutual learning and comparison [6]. As shown in the previous link, problems in the learning process have been solved. Therefore, after class, students improve their learning results once again. When they come back to class, it is basically the students' Show time, and their confidence is improved, so that they can better prepare for the next task in advance and show themselves better in front of classmates.

This link is based on the above teaching process. If there are defects in the previous task execution, it can be improved and made up through this link. Then the teacher and students prepare for the next class together.

At the end of the experiment, the students of the two classes took part in the English-Chinese and Chinese-English text translation tests at the same time, and then conducted independent tests. Finally the experimental results are analyzed. The experimental results are analyzed as shown in Table 1.

The scores of the two classes before the experiment were $\mathrm{P}=0.265>0.05$, and the difference was not significant, which indicated that before the flipped classroom mode teaching, there was no difference in knowledge acquisition between 
the two classes, and this experiment could be carried out between the two classes. After the flipped mode teaching, $\mathrm{P}=0.002<0.05$, indicating a significant difference between the two classes.

This shows that after the implementation of flipped classroom teaching, there is a significant difference between the test scores of the two classes in terms of mastering knowledge. Then, the difference between the two tests before and after the shift was further analyzed, $\mathrm{P}=0.000<0.05$, with significant difference. This result shows that after this semester's flipped teaching, the experimental class has a significantly higher level of knowledge acquisition than the control class, which proves that flipped teaching plays an important role in MTI students' knowledge acquisition.

In order to understand the effect of flipped classroom teaching and students' feelings on flipped classroom teaching reform, the author conducted a questionnaire survey and interview on students in his own class.

In this survey, 36 questionnaires were distributed and 36 valid ones were collected. According to the questionnaire statistics, flipped classroom teaching was welcomed and affirmed by the majority of students. But due to the lack of independent learning and learning habits, the effect is not as expected. The English teaching of MTI flipped classroom still needs to be improved and the typical statistics are shown in Table 2.

The survey results show that more than $80 \%$ of students approve of the application of flipped classroom model in teaching. They believe that this teaching

Table 1. Statistical table of students' test data.

\begin{tabular}{ccccc}
\hline \multirow{2}{*}{\begin{tabular}{c} 
The number of students \\
\cline { 2 - 4 }
\end{tabular}} & $\begin{array}{c}\text { Before the } \\
\text { experiment }\end{array}$ & $\begin{array}{c}\text { After the } \\
\text { experiment }\end{array}$ & $\begin{array}{c}\text { Score Difference of } \\
\text { Pre-test and Post-test }\end{array}$ \\
\hline Experimental Class & 18 & $76.30 \pm 6.36$ & $83.04 \pm 5.81$ & $6.74 \pm 2.46$ \\
Control class & 18 & $77.61 \pm 5.48$ & $79.40 \pm 5.56$ & $1,79 \pm 2.11$ \\
P Value & & 0.265 & 0.002 & 0.000 \\
\hline
\end{tabular}

Table 2. Problems and data statistics.

\begin{tabular}{ccccc}
\hline \multirow{2}{*}{ Questions } & \multicolumn{4}{c}{ Options and Statistics } \\
\cline { 2 - 5 } & $\begin{array}{c}\text { Approval } \\
(\text { A }+++++)\end{array}$ & $\begin{array}{c}\text { Approval } \\
(\text { A++) }\end{array}$ & $\begin{array}{c}\text { Approval } \\
\text { (A) }\end{array}$ & Disapproval \\
\hline $\begin{array}{c}\text { Conducive to the learning } \\
\text { and application of English }\end{array}$ & $66 \%$ & $20 \%$ & $12 \%$ & $2 \%$ \\
$\quad \begin{array}{c}\text { Good for English } \\
\text { learning efficiency }\end{array}$ & $72 \%$ & $18 \%$ & $8 \%$ & $2 \%$ \\
$\begin{array}{c}\text { To improve the initiative and } \\
\text { participation of learning English } \\
\begin{array}{c}\text { To facilitate the improvement } \\
\text { of English communication }\end{array}\end{array}$ & $70 \%$ & $20 \%$ & $10 \%$ & $0 \%$ \\
\hline
\end{tabular}


model can improve students' learning of English knowledge and stimulate their interest in learning English. In addition, it is conducive to improving learning efficiency and English communication ability, and more than $90 \%$ of students believe that this teaching method can improve the initiative and participation in English learning.

\section{Conclusions}

The paper designs the teaching mode of university flipped classroom, takes pre-class, in-class and after-class activities as the teaching process, proves its application effect through teaching experiments, and investigates the acceptance of this teaching mode by university students. In this way following conclusions are drawn: Compared with the traditional teaching mode that focuses on knowledge transmission, flipped classroom teaching has some obvious advantages and attractions. For example, it can give full play to students' subjective initiative, strengthen communication with students, stimulate students' interest in learning, and activate the atmosphere of classroom teaching. The application of flipped classroom model in teaching can improve students' learning effect, optimize the learning process and improve students' learning attitude.

From the perspective of research, the above research subjects are relatively few or lack of control group. However, the above research conclusion illustrates the commonality of flipped classroom in China from one side: flipped classroom teaching mode has its growth conditions and reasons.

In this study flipped classroom reconstructs the definition of teacher and teaching. The combination of two methods can change the current teaching mode, further research is needed. Therefore the majority of teachers and educators will constantly accumulate experience in the practice of flipped classroom in order to gradually improve the teaching model suitable for flipped classroom.

\section{Acknowledgements}

1) The research is achievement of Research Project on Major Theoretical and Practical Problems in Shaanxi Province, China (2018C066); 2) The research is supported by Fundamental Research Fund for the Central Universities of China (3102017jc19006); 3) The research is supported by Degree and Graduate Education Research Fund of NPU (2018AC13).

\section{Conflicts of Interest}

The authors declare no conflicts of interest regarding the publication of this paper.

\section{References}

[1] Jensen, J.L., Kummer, T.A. and Godoy, P.D. (2015) Improvements from a Flipped Classroom May Simply Be the Fruits of Active Learning. J. Life Sciences Education, No. 14. https://doi.org/10.1187/cbe.14-08-0129 
[2] Bretzmann, J. (2013) Practical Strategies for Flipping Your Class. The Bretzmann Group, New Berlin.

[3] Strayer, J.F. (2012) How Learning in an Inverted Classroom Influences Cooperation, Innovation and Task Orientation. J. Learning Environments Research, 15.

[4] Baker, J.W. (2000) The Classroom Flip: Using Web Course Management Tools to Become the Guide by the Side. 11 th international Conference on College Teaching and Learning, Jacksonville, Florida Community College.

[5] Fulton, K. (2012) Upside Down and Inside Out: Flip Your Classroom to Improve Student Learning. J. Learning \& Leading with Technology, 39.

[6] Tune, J.D., Sturek, M. and Basile, D.P. (2013) Flipped Classroom Model Improves Graduate Student Performance in Cardiovascular, Respiratory and Renal Physiology. J. Advances in Physiology Education, 37. 